\title{
Videos Available for Loan from the University of Virginia
}

The Center for Russian and East European Studies at the University of Virginia has videos related to Slavic folklore which they are willing to loan out for a small shipping and handling fee. They ask only that you request materials at least ten days in advance and that you provide a school address for delivery. The period of the loan is ten days, although extensions may be made by phone or e-mail if the video has not been otherwise reserved. For information you can contact either Allen Lynch, the Director of the Center, or Pat. B Wilson, his administrative assistant. The Center may be contacted at:

\section{Levering Hall \\ University of Virginia \\ Charlottesville, Virginia 22903}

They may also be reached by phone as (804) $924-3033$ and by fax at (804) 924-7867. Ideally they would prefer to communnicate with patrons entirely through e-mail at crees@virginia.edu. The following descriptions are from their catalogue.

\section{A Partial List of Available Videos}

\#V220a The Treasure of Rogozen (19 minutes, PAL) Bulgarian dubbed into English. Presents the history of the treasure's discovery, an analysis of its origins and an explanation of its mythological content. 
\#V220c The Folk Song and Dance Ensemble from the Town of Yambol [Bulgaria] (57 minutes) A full concert performance by the ensemble.

\#V220d The "Rodopa State Folk Song and Dance Ensemble from the Town of Smolyan [Bulgaria] (53 minutes) A concert performance.

\#V220e The "Trakiya" Folk Song and Dance Ensemble from the Town of Plodiv [Bulgaria] (59 minutes) A concert performance.

\#V290 Earth (54 minutes) Silent with English, 1930. A great masterpiece - the fourth and last silent film by Dovzhenko, a lyrical evocation of his native Ukraine, the theme of the life cycle of a man developed through the constant juxtaposition and intertwining of images of life and death.

\#V295 East of Europe (50 minutes) Color, 1987. Part of the BBC Triumph of the West Series, this documentary explores the issue of whether Russia is part of the East or West. Cultural, historical, and geographical influences on the development of Russia are explored and analyzed. John Roberts looks beyond Cold War definitions as he considers how Byzantines, Bulgars, Ottoman Turks, Slavs, and Mongols all made their mark on Europe in the East and contributed to the Russian enigma. A good film to begin a course of study in Russian or Soviet culture.

\#V380 Gypsies (30 minutes) Black and White, 1961. A cinema-verité style documentary film directed by Wladyslaw Slesicki that follows a traveling gypsy caravan across rural Poland. Original synchronous sound, no commentary.
\#V547 Luchak's Easter (30 minutes) Color, 1973. This film discusses the Easter ritual in the Ukrainian community of Albertak, Canada. Filmed by the Canadian Centre for Folk Cultures Studies.

\#V740 Russian Folk Song and Dance (78 minutes) Color. Four of Russia's greatest troupes performing their colorful, melodic songs and dances produce a comprehensive overview of tradition and create a stirring picture of Russian musical and dance history.

\#V945 The Ukrainian Easter Egg [also called Pysanka] (14 minutes) Color, 1976. An award-winning film detailing the decoration of Ukrainian Easter eggs.

\#V1043 Ukrainian Dance (30 minutes) Color. Three of the best dance ensembles from across Ukraine in performance, accompanied by the renowned instrumental enseinble Troist Muzyky from Kyiv. The dancers will thrill you with traditional stage choreography and character dances beautifully filmed at various historical locations around Ukraine.

\#V1038 Dudaryk Boys' Choir Christmas Eve Concert (50 minutes) The world renowned Dudaryk Boys' Choir from Lviv sings traditional Ukrainian Christmas carols accompanied by members of a medieval woodwind quartet. 